Binghamton University

The Open Repository @ Binghamton (The ORB)

2012

\title{
Global Health Impact: A Basis for Labeling and Licensing Campaigns?
}

Nicole Hassoun

Binghamton University--SUNY, nhassoun@binghamton.edu

Follow this and additional works at: https://orb.binghamton.edu/philosophy_fac

Part of the Philosophy Commons

\section{Recommended Citation}

Hassoun, Nicole, "Global Health Impact: A Basis for Labeling and Licensing Campaigns?" (2012).

Philosophy Faculty Scholarship. 12.

https://orb.binghamton.edu/philosophy_fac/12

This Article is brought to you for free and open access by the Philosophy at The Open Repository @ Binghamton (The ORB). It has been accepted for inclusion in Philosophy Faculty Scholarship by an authorized administrator of The Open Repository @ Binghamton (The ORB). For more information, please contact ORB@binghamton.edu. 
Global Health Impact:

A Basis for Labeling and Licensing Campaigns? ${ }^{\mathrm{i}}$

\section{Introduction}

Every year 9 million people are diagnosed with tuberculosis, every day more than 13,400 people are infected with AIDS, and every 30 seconds malaria kills a child. ${ }^{\text {ii }}$ About a third of all deaths, 18 million a year or 50,000 every day, are poverty-related..$^{\mathrm{iii}}$ Most of the world's health problems afflict poor countries and their poorest inhabitants. ${ }^{\text {iv }}$ There are many reasons why so many people die of poverty-related causes. ${ }^{v}$ One reason is that the poor cannot access many of the existing drugs and technologies they need. Another is that little of the research and development (R\&D) done on new drugs and technologies benefits the poor. There are several proposals on the table that might incentivize pharmaceutical companies to extend access to essential drugs and technologies to the global poor. ${ }^{\text {vi }}$ Still, the problem remains - the poor are suffering and dying from lack of access to essential medicines. So, it is worth considering a new alternative. This paper suggests rating pharmaceutical and biotechnology companies based on how some of their policies impact poor people's health. It argues that it might be possible to leverage a rating system to encourage companies to extend access to essential drugs and technologies to the poor.

Consider a few possible uses for a rating system that this paper will explore more fully below. One possibility is to give the highest rated companies, in given year, a "Global Health Impact" label to use on their products. These companies would then have an incentive to use the label to garner a larger share of the market as those engaged in trade and investment may prefer to purchase goods and invest in companies that help the poor. Other labeling campaigns include Fair Trade, Organic, Ethos, RED, and the Sustainable Forestry Initiative. Having a rating system for pharmaceutical and biotechnology companies would also open the door to all kinds of fruitful social activism including global health licensing campaigns. Pharmaceutical and biotechnology companies rely, to a large extent, on university research and development. So, if universities give preference to highly-rated companies in licensing their technology, companies will have an incentive to become highly rated. This idea is along the lines of the Universities Allied for Access to Essential Medicines licensing campaign. A rating system, even with an associated 
labeling and licensing campaign, will not solve all of the poor's health problems. Nevertheless, this proposal has some advantages over and might be used in conjunction with existing proposals. Together they may have a significant impact on access to essential drugs.

\section{Creating a Good Rating System}

One possible rating system is the recently released Access to Medicine Index publicized by the New York Times, which rates companies based on their policies but does not (yet) provide the basis for a labeling or licensing campaign. ${ }^{\text {vii }}$ The Access to Medicine Index rates companies along several dimensions including their $\mathrm{R} \& \mathrm{D}$, patenting, pricing, and drug donation programs. It aims to improve access to medicine. $^{\text {viii }}$

\section{Select Access to Medicine Index Ratings}

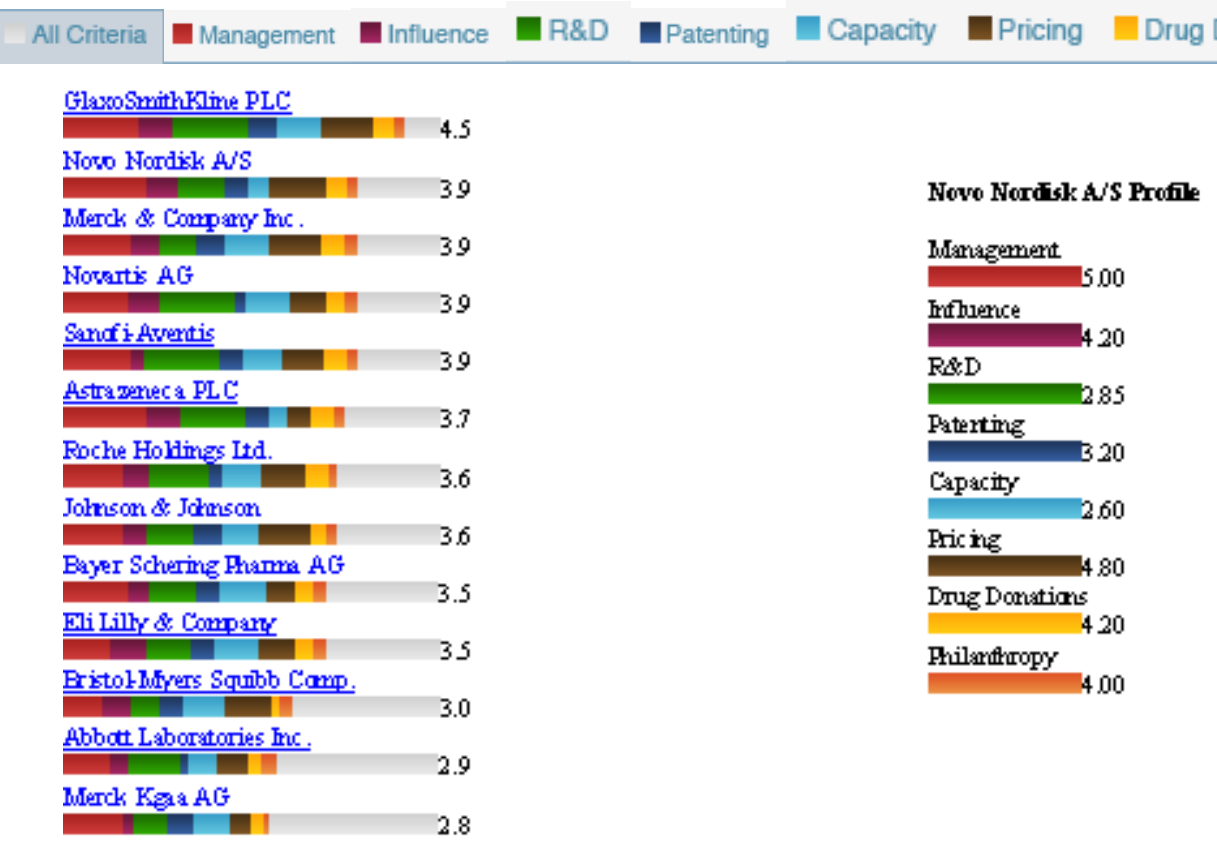

Figure 3. Select Access to Medicines Index Ratings ${ }^{\mathrm{ix}}$

Unfortunately, the Access to Medicine Index has some serious problems. Its ratings are primarily subjective and may be unduly influenced by irrelevant information. The index solicits input from many "stake-holders" (pharmaceutical companies, doctors, non-governmental organizations etc.) irrespective of whether their interests compete with the interests of the poor. It is not clear what impact different interest groups have on the final rating. Another problem is that the index gives companies credit just for having 
good policies in place (more than $50 \%$ of the original Index was policy-based). This is analogous to rewarding someone based on how they say they are going to carry out a project. As anyone familiar with Enron's official code of ethics knows, good policies do not guarantee good outcomes.

A better rating system would be objective and output-based. ${ }^{x}$ That is, it would reward companies based on how their R\&D results and charitable contributions etc. actually impact poor people's health. It would not just reward companies based on the amount of resources they put into creating and helping poor people access essential drugs and technologies. Companies rewarded for their investments might make it seem like they are investing more in helping the poor than they are. This is a real concern given that biotechnology and pharmaceutical companies may already be exaggerating their R\&D costs. ${ }^{\mathrm{xi}}$ Furthermore, rewarding investments creates no incentive for companies to be efficient and productive. If what we really care about is whether the poor can access essential drugs and technologies, it is probably better to reward companies based on how much their policies actually increase access.

To create an objective, output-based rating system researchers should probably look at many aspects of companies' R\&D and charitable endeavors. ${ }^{\text {xii }}$ Researchers might consider, for instance, how much each company's charitable contributions are doing for the poor by looking at its a) drug donations, $b$ ) price reductions, c) approved and verifiable health-projects (e.g. health-related infrastructure improvements in developing countries), d) technology transfer programs for developing countries and e) efforts to enhance developing countries' research capacities. ${ }^{\text {xiii }}$ The goal would be to measure the number of disability adjusted life-years (DALYs), or whatnot, companies' R\&D and charitable efforts are averting in developing countries. ${ }^{\text {xiv }}$

Consider here just one way of rating companies' R\&D output. ${ }^{\mathrm{xv}}$ It would take a very long time to look at all the drugs each company produces, even in a given year. Fortunately, researchers might estimate companies' R\&D output by looking at all the US Food and Drug Administration approved "orphan" drugs and seeing how much each could alleviate the global burden of disease (GBD). Orphan drugs are those that biotechnology and pharmaceutical companies expect (or say they expect) to have very small markets in the US. ${ }^{\text {xi }}$ So the drugs and technologies for neglected diseases that researchers would want to incentivize companies to produce should be listed as orphan (companies already have incentives to produce drugs and 
technologies for which there is a large US market). ${ }^{\text {xvii }}$ Some orphan drugs will not help the poor and there is an incentive for companies to get as many drugs as possible listed as orphan because they get up to a $50 \%$ tax credit for testing orphan drugs. ${ }^{\text {xiii }}$ Researchers might, however, do an effectiveness analysis on orphan drugs that address neglected diseases to estimate how much each of these drugs will help the poor.

Although there are different ways of doing effectiveness analysis and the calculations can get quite complex, the basic idea is simple. First, look at each drug's market price and the amount of need equivalent dosages of each will fulfill in developing countries (e.g. in DALYs). ${ }^{\text {ix }}$ The amount of need equivalent dosages of a drug will fulfill might be calculated using the DALY information in the WHO's Global Burden of Disease study and drug efficacy estimates from clinical trials or meta-analyses of such data. ${ }^{\mathrm{xx}}$ Suppose of the 34 million DALYs lost to malaria in $2004,80 \%$ can be attributed to plasmodium falciparum (the worst kind of malaria). ${ }^{x x}$ Quinine is effective in about $9 \%$ of cases. ${ }^{x x i i}$ So, Quinine probably averted about 2.5 million DALYs.

The next step is to rate companies on the basis of their inventions' impact -- aggregating their individual inventions' impacts (in terms of DALYs averted). Suppose Pfizer has three drugs that avert the loss of 1.1, 1.5 and 2.1 million DALYs, respectively. Suppose Bayer has two drugs that avert the loss of 2.2 and 2.4 million DALYs, respectively, Bayer may be ranked above Pfizer. Bayer's drugs avert 4.7 million DALYs, while Pfizer's avert 4.6 million DALYs.

There may be good reasons to modify this kind of rating system. To insure that companies do not get too much credit for producing slight variations on standard drugs and technologies, it might be good to consider how much improvement each drug offers over the next best alternative. ${ }^{x i i i}$ To do this it might suffice to simply subtract the expected benefit to the poor of the best old drug or technology from the expected benefit of the new drug or technology. ${ }^{\text {xxiv }}$ Companies would, however, receive credit if their products alleviate more disease because they have better pricing strategies, for instance, even if their drugs offer no new therapeutic improvements. ${ }^{\mathrm{xxv}}$

The details of this schema would have to be worked out carefully and might diverge significantly from those suggested here. Economic analysis might help maximize the positive impact on the poor. It might be more difficult to capture the impact biotechnology and pharmaceutical companies are having on 
the poor than to create standards for good working conditions as the Workers' Rights Consortium has tried to do. Still, there is a lot of work on effectiveness analysis in the literature. ${ }^{\text {xxvi }}$ This work might also provide the basis for evaluating companies' charitable efforts. ${ }^{\text {xxvii }}$

If it is too difficult to find verifiable information on the impact of some of companies' charitable or R\&D endeavors, that may not present an insurmountable obstacle for a rating system. It may be possible to start with the available information, eliciting more information as a condition of rating companies once the system is in place. ${ }^{\text {xviii }}$ Some information is sensitive, but if companies want to compete for ratings, they have an incentive to release it. Furthermore, companies may benefit in other ways from providing some of this information to the public. Perhaps this is why many companies are already collaborating with researchers to document their charitable and drug donation programs. ${ }^{\text {xxix }}$

Another reason for optimism is that, the rating system need not be very precise. It just matters that researchers establish a feasible bar over which companies must pass to receive GHI certification and that a rating system yields the correct ordinal ranking of companies. So, even if a rating system is initially quite imperfect, that may not be a problem.

It is important, however, that the index encourage companies to make sustainable changes in their policies for the long term rather than just pursue policies that pay off in the short term. The idea is to reward them for their impact on global health over time. So it is important that the rating system itself is in place for a long time, and gives appropriate weight to rewarding long term investments that actually improve poor peoples' health.

A good rating system should probably be developed and administered by an appropriately impartial and transparent rating organization. Perhaps a non-governmental group like Doctors Without Borders or the World Health Organization would be willing to develop and oversee such a project. If the organization does not have the relevant research capacity, it might partner with academics specializing in health evaluation methodologies. Alternately, governments or international organizations might develop the rating system and provide the requisite oversight (as the US government does with the USDA Organic label and the International Standardization Organization does with the ISO 14000 environmental management standards). ${ }^{\mathrm{xx}}$ In either case, however, input from all the relevant stakeholders including biotechnology and 
pharmaceutical companies may be essential to create a good and sustainable rating system. This will help insure that companies get credit for as many of the good things they are doing as possible and may expose potential areas of abuse.

Finally, a good rating organization should probably have a review panel to address unforeseen problems as they arise. This panel can hear objections to allowing a company to receive credit for a proposed project and alter the rating system as necessary. ${ }^{\mathrm{xxi}}$ It is impossible to foresee every problem. It may also be counter-productive to spend time worrying about problems that may not arise.

\section{Global Health Impact (GHI) Labeling}

One way of encouraging biotechnology and pharmaceutical companies to extend access to essential drugs and technologies to the poor with a rating system like that described above is to create a Global Health Impact (GHI) label that they can use on their products. Then, these companies will have an incentive to voluntarily use the label to garner a larger share of the market. If Wyeth, for example, was highly rated, Wyeth could use the GHI label on Advil. Wyeth would have an incentive to do so because consumers and doctors might, in some cases, prefer to purchase and prescribe GHI Advil over the alternative analgesics. If even a small percentage of consumers or doctors would prefer GHI products, the incentive to use this label for analgesics alone could be significant in this approximately two-billion dollar a year market. ${ }^{\text {xxxii }}$ (Note: The top ten analgesic pills seem to capture between 2-14\% of the market each and they are all available over the counter from Walgreens and other pharmacies). ${ }^{x x x i i i}$ This proposal might be useful wherever there is a market for companies' products.

It is worth exploring this option, given the success of other labeling campaigns. Fair Trade campaigns have, for instance, been quite successful. In 2000, European countries sold 27 million pounds of coffee worth more than 300 million dollars. ${ }^{\text {xxxiv }}$ Fair Trade coffee sales amounted to about 1.2 percent of the European market. ${ }^{\mathrm{xxv}}$ About 50,000 retail outlets (97\% of roasters) including Starbucks, Peets, and Green Mountain coffee sell Fair Trade certified coffee, even Exxon Mobile sells the stuff. ${ }^{\text {xxxi }}$ And it is not just coffee. By 2007, Fair Trade certified sales were approximately $€ 2.3$ billion. ${ }^{\text {xxvii }}$ RED and Buy Pink - for companies willing to donate a portion of the sale of a product to AIDS and breast cancer research - have also been quite successful. RED has provided 150 million dollars to the Global Fund and is one of its 
largest contributors, for instance. ${ }^{\text {xxviii }}$ USDA Organic label, LEED certification for green buildings, and FCS and Smart Wood Certified Forestry sustainable forestry labeling are likewise growing. Ethical consumption, supported by such campaigns, is generally on the rise. In the UK, for instance, expenditure on ethical goods and services in energy, housing, household goods, transportation, personal items, and subscriptions almost doubled between 2002-2007. .xxix $^{\text {. }}$

Furthermore, there is reason to think that a GHI label, in particular, could create large incentives for positive change. ${ }^{\mathrm{xl}}$ One percent of the market in analgesics alone is 20 million dollars. ${ }^{\mathrm{xli}}$ Markets for other pharmaceutical products are much larger. The US market for prescription allergy medicines in 2001 alone generated revenues of more than $\$ 6.45$ billion (1.7 billion came from over the counter allergy and asthma products before Claritin, Allegra, and Zyrtec were off prescription). ${ }^{\text {xlii }}$

Patients, doctors, and insurance companies will not always prefer GHI drugs and technologies. Sometimes there will be one medicine that is best for a particular condition in which case its GHI status may not matter. In many cases it would not even be a good idea for patients, doctors, or insurance companies to choose GHI products if they are not the best choice for a particular disease or disability.

Many drugs have equally good competitors, however. In 2006, $63 \%$ of all prescriptions were for generic drugs. When there is an equally good competitor for drugs under patents, patients, doctors, and insurance companies might take the ratings into account. ${ }^{\text {xliii }}$ Furthermore, many over-the-counter medications have equally good competitors. The market for over the counter medicines in 2004, alone, was US $\$ 16$ billion. ${ }^{\text {liv }}$ This market includes many drugs made by major pharmaceutical companies including Nicorette, Monistat, and Claritin that have reasonable competitors.

If generic companies were also rated (e.g. on the basis of their drug donation programs and charitable contributions) the potential impact of GHI labeling would be even larger. The market for generics is over 20 billion and consumers are often indifferent (or nearly indifferent) between generics and other medicines. ${ }^{x l v}$ So the fact that pharmacies usually do not carry more than one generic of the same molecule should provide no objection to this proposal (people might prefer a GHI certified generic medication to its patented competitors). If consumption of GHI goods reached $1 \%$ of the market in overthe-counter and generic medications -- - that would yield at least 3.6 billion dollars worth of incentive for 
biotechnology and pharmaceutical companies to become GHI certified. ${ }^{\text {xlvi }}$ This number looks big enough to incentivize even Pfizer to do some good.

Furthermore, pharmaceutical companies make all kinds of products besides drugs - from diet drinks to lotion and pet vitamins to mouth wash. Pfizer, for instance, makes parasiticides, anti-infectives, biologicals, allergy, cancer, pain, metabolic disease, production, nutritionals, and food safety products for animals. Besides their pain management, dietary supplements, respiratory, topical, and GI medicines for people, they have "a full line of infant formulas, follow-on formulas, growing-up milks, and prenatal and adult supplements." ${ }^{\text {’lvii }}$ So, they could use the GHI label on these products too.

Finally, insurance companies might create additional incentives for companies to extend access to essential drugs and technologies to the poor. Both (public and private) insurance companies could create incentive for positive change by giving (some) preference to (otherwise equivalent) GHI drugs on their formularies. They might even be encouraged to do so if a similar rating system were designed to measure insurance companies' impact.

Having different (e.g. gold and silver star) labels might also help ensure that the GHI rating system does not just "rubber stamp" what may be genuinely bad behavior on the part of biotechnology and

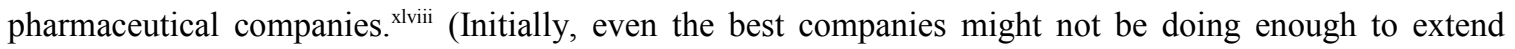
access to essential drugs and technologies to the poor.)

Even in the absence of a complete account of companies' obligations or multiple labels, however, a GHI rating agency can avoid condoning bad behavior in other ways. Just as it is possible to reward a generally bad employee or child for doing something right, it is possible to reward a generally bad company for good behavior. It is just essential that everyone utilizing the GHI label is clear about exactly what it does and does not mean.

Although some companies may try to undercut the GHI label or game the system by, for instance, lobbying the rating agency or creating counterfeit labels, there are also reasons for highly ranked companies to support it. If the rating standards are transparent and simple, and consumers and health care professionals are educated about the GHI label, it might be widely trusted and alternatives viewed with 
suspicion. This seems to be the case with Fair Trade labels, for instance. ${ }^{x l i x}$ Governments might even regulate use of the label as the US did, however imperfectly, with "Organic" labels.'

\section{GHI Licensing}

Having a GHI certification system for biotechnology and pharmaceutical companies would also open the door to many other ways of incentivizing companies to extend access to essential drugs and technologies to the poor. Activists who believe people have a human right to essential drugs and technologies might, for instance, organize boycotts of non-essential medicines produced by companies that are not GHI certified (just like animal rights advocates organized boycotts of tuna caught by companies that did not use dolphin safe nets). Alternately, socially responsible investment companies could include in their portfolio GHI companies. ${ }^{\text {li }}$ Such activism might positively impact the poor's access to essential drugs and technologies.

GHI might even encourage new kinds of social activism. An organization along the lines of Universities Allied for Access to Essential Medicines (UAEM), which promotes licensing practices to help the poor, might create a campaign to get universities to develop "GHI licensing" policies..$^{\text {lii }}$ Alternately, the American Medical Student's Association, which uses metrics to put pressure on pharmaceutical companies and universities to improve policies, might launch a GHI licensing campaign. Since UAEM has already had some success with getting universities to accept their (very important) Equitable Access License (i.e. openaccess license), there is reason for optimism. . iii $^{\text {ii }}$

Pharmaceutical and biotechnology companies rely, to a large extent, on university research and development. Universities have developed many drugs and technologies including vaccines, tests for osteoporosis and breast cancer, and the "gene splicing technology that initiated the biotechnology industry." liv Many big pharmaceutical companies license in or acquire a large percentage of their drugs (by, say, purchasing small biotech companies) from universities. " "In 2002, for example, Pfizer licensed in 30 percent of its drugs, and Merck 35 percent." ${ }^{\text {"vi }}$ All of Bristol-Myers Squibbs' best selling drugs in 2003

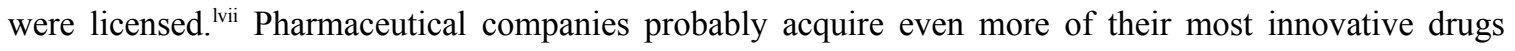
from universities. ${ }^{\text {lvii }}$ "Nearly all HIV/AIDS and cancer drugs are based on outside research -- most of which 
is university research sponsored by the NIH." ${ }^{\text {lix }}$ In 2000, a US Senate report found that federal funding supported the development of 15 of the 21 most important drugs. ${ }^{\text {Ix }}$

On a conservative estimate, about a third of all $R \& D$ is done by universities in high income countries. The percentage may be even greater as companies have a large incentive to over report $R \& D$ and include marketing costs as R\&D. ${ }^{\text {lxi }}$

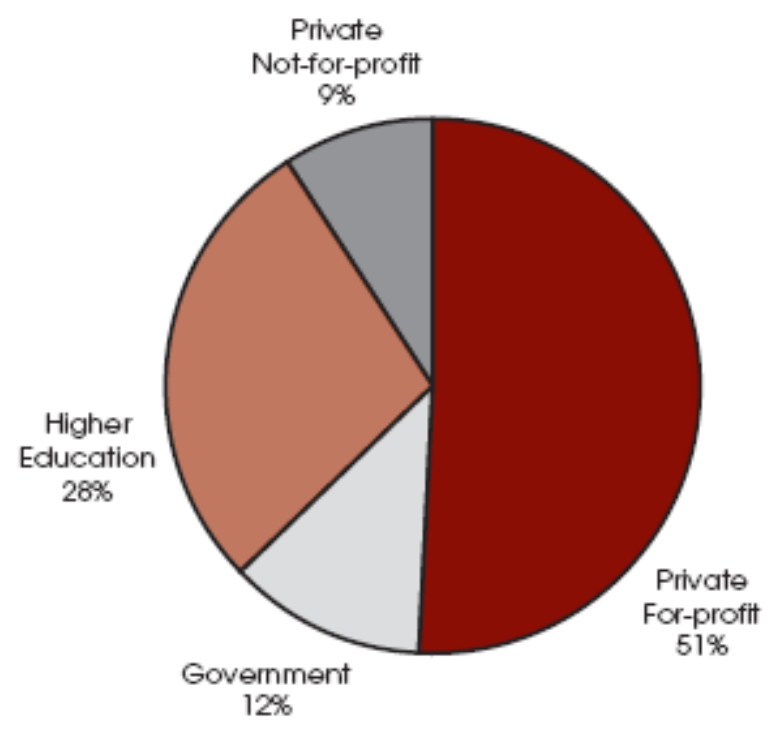

Figure 4: R\&D in High Income Countries ${ }^{\text {lxii }}$

This was not so a few years ago. In 1980, congress passed the Bayh-Dole act which allowed universities to patent their research and to license it to third parties. ${ }^{\text {xiii }}$ Before the act was passed, universities received less than 250 patents a year. In 1996, universities received over 2,000 patents, "executed nearly 2,200 licensing agreements, and received royalty income from licensing of $\$ 242$ million. ${ }^{\text {"xiv }}$ Between 1980-2007, over 1,500 start-up companies were formed from academic research. ${ }^{\text {lxv }}$ In 2005 , there were at least 28,349 active licenses. ${ }^{\text {lxvi }}$

Furthermore, there is reason to believe pharmaceutical companies are coming to rely more and more on universities. Recently in-house pharmaceutical research has not been very productive. ${ }^{\text {Ixvii }}$ In light of its dry pipeline, the pharmaceutical industry is "searching ever more desperately for drugs to license from small biotechnology companies and universities." ${ }^{\text {xviii }}$ 
Because biotechnology and pharmaceutical companies depend to a great extent on university's licenses, universities could, conceivably, influence these companies' policies. ${ }^{\text {Ixix }}$ If, for instance, universities' licensing agreements required preferential treatment of companies that were highly rated, companies would have an incentive to meet GHI standards. ${ }^{1 \mathrm{xx}}$ Universities might adopt a GHI licensing policy voluntarily. Their technology transfer offices could agree to implement GHI licensing practices. At the University of Pittsburgh, for instance, the head of the Office of Technology Management has this decision making capability. Though, he would probably also require the support of the chancellor if the policy negatively impacted the university's ability to sell licenses. ${ }^{\mathrm{lxi}}$ Depending on how the GHI standards are set, the policy might not negatively impact the sale of university licenses. At least it is worth carrying out the requisite econometric analysis to determine the likely impact on all of the relevant stake-holders (including universities and the poor).

Technology transfer offices already use some non-financial criteria when deciding to whom to license their products. The Bayh-Dole act encourages universities to license to small, US companies. Universities acquiesce without complaint.

If the technology transfer offices at some universities are reluctant to sign on to voluntary programs, however, professors and researchers might have an impact because they sign agreements to allow universities to license patents resulting from research they create. Although some researchers at major universities receive industry funding, only $7 \%$ of university research is funded by industry. ${ }^{\text {Ixxii }}$ Pharmaceutical funding probably makes up only a portion of the total. .xxii $^{\text {ii }}$

Universities might be receptive to the idea since:

...universities hold an avowed commitment to creating and disseminating knowledge for the public good, and they have pledged to see the technologies they develop deployed to benefit the world. Campus decision makers are insulated from lobbies that may dominate political arenas; they are expected to be responsive to students and faculty; and they operate in an environment where reasoned debate, not power, is expected to be the currency. ${ }^{1 \times x i v}$

As the Association of University Technology Managers put it, universities are not only concerned about monetary benefits but want the new drugs and technologies they develop to "be used to further the public good." $" 1 \times x v$ 
Students could also encourage professors and universities to make the necessary revisions. They might follow United Students against Sweat Shops' (USAS') example. USAS has helped convince campuses to buy "sweat-free" clothing made at factories approved by the Worker Rights Consortium. Alternately, students might emulate Universities Allied for Access to Essential Medicines (UAEM). UAEM has convinced universities to adopt Equitable Access (i.e. open access) licensing policies. ${ }^{\text {lxvi }}$ If a GHI licensing campaign was only as successful as USAS's campaign has been so far, this proposal could create 840 million dollars worth of incentive for pharmaceutical companies to become certified every year. ${ }^{\text {lxxvii }}$ That is about the cost of developing a new drug on the highest estimates. ${ }^{\text {lxviii }}$ This incentive might suffice to double the number of drugs produced for neglected diseases between in 1975-1999 in a similar time-frame. ${ }^{1 \times x i x}$

\section{Advantages of the GHI Proposals}

GHI labeling and licensing have some advantages over and avoid some of the problems with the main alternatives. One advantage is that it might both help the poor access existing drugs and technologies and encourage new R\&D for the poor. Most of the alternatives address only one of these problems.

Consider, first, just a few alternatives to help the poor access existing drugs and technologies. It is impossible to canvass every proposal in the literature here. ${ }^{\mathrm{Ixx}}$ There are many innovative licensing and intellectual property strategies not discussed below that merit serious consideration, for instance. ${ }^{\text {lxxi }}$ One way of lowering the cost of existing drugs and technologies is via differential pricing. ${ }^{\text {lxxii }}$ Biotechnology and pharmaceutical companies might offer drugs at different prices for different markets. ${ }^{\text {Ixxiii }}$ Another option is compulsory licensing. Countries can issue licenses to produce and/or import these products without approval by the company holding the patent. Yet a third way of lowering the cost of existing drugs and technologies is to repeal the World Trade Organization's Trade Related Intellectual Property Rights Agreement (TRIPS) or, barring that, modify it to allow poor people to secure essential medicines at or below the marginal costs of production. ${ }^{1 \times x x i v}$

Although companies do some differential pricing, they have also resisted differential pricing. ${ }^{\text {Ixxv }}$ In some cases, companies may suffer financially if they lower their prices for the poor. It may be hard to prevent re-importation of cheaper versions of identical-drugs across borders, even with different packaging. 
So, it is not likely that companies will pursue differential pricing to the extent required to protect global health.

Similarly, companies often resist compulsory licensing. When South Africa passed its Medicines Act, many of the big pharmaceutical companies sued because the act encouraged generic competition for AIDS medicines. ${ }^{\text {Ixxxi }}$ It was only after protracted negotiations, and a great deal of negative media attention, that the pharmaceutical companies withdrew their lawsuit. South Africa did not go on to import generic AIDS medicines. ${ }^{1 \times x x v i i}$ At the behest of companies, other countries have been singled out in the 301 Reports of the US Trade Representative for not being aggressive enough in enforcing foreign intellectual property rights and have, thus, faced the threat of trade sanctions. ${ }^{1 \times x x v i i i}$ The US has also used bilateral trade agreements and "diplomatic and political pressures to undermine countries that produce generic medicines and/or consider importing them."1xxxix

Worse countries without their own manufacturing capacity may not be able to secure the drugs they need even if they do issue compulsory licenses. ${ }^{x c}$ TRIPS requires countries like India, Brazil, and Thailand that export essential drugs and technologies to issue compulsory licenses to do so. ${ }^{\text {xci }}$ So far, only one country (Canada) has agreed to export drugs under a compulsory license. ${ }^{\text {xii }}$ It issued a compulsory license to export TRIPVAR, an AIDS medication, to Rwanda. ${ }^{x i i i}$ Though, given the complexity of international and Canadian law, Canada was yet to export a single pill three years after issuing the license. ${ }^{\text {xiv }}$

Finally, there was a large social movement, backed even by the (then) Pope, to prevent implementation of the TRIPS agreement. ${ }^{\text {xcv }}$ Ultimately, it failed. ${ }^{\text {xcvi }}$ Biotechnology and pharmaceutical companies want control over the drugs they develop in every market. So it is unlikely that there will be a return to the pre-TRIPS situation or even that the agreement will be modified substantially to reduce prices in poor countries. ${ }^{\text {xvii }}$

Alternatives to GHI that encourage R\&D on essential drugs and medications for neglected diseases include prize funds and grants. ${ }^{\text {xviii }}$ Agencies or individuals often agree to buy a certain number of doses from any company that develops a malaria vaccine at a set price. Foundations often give grants for 
research on neglected diseases. ${ }^{\text {xix }}$ The Gates' Foundations recently partnered with Novartis to support testing of new antibiotics for TB, for instance. ${ }^{\mathrm{c}}$

Neither alternative takes full advantage of the efficiency the free market offers. The agencies offering prize funds or grants have to decide what neglected diseases or problems they want to address and there may be better ways to help the poor. They also have to decide how much a given intervention is worth. "These decisions are likely to be associated with substantial inefficiencies due to incompetence, corruption, lobbying by companies and patient groups, and gaming."

Adian Hollis' and Thomas Pogge's alternative is to create a second (voluntary) patent system. ${ }^{\text {cii }}$ Under this system, biotechnology and pharmaceutical companies would not be given a limited monopoly for their inventions. Rather, inventors would be rewarded based on how much their inventions contribute to ameliorating the GBD. Inventors would have an incentive to invest in whatever R\&D, infrastructure improvements, pricing systems, or donation programs would make the most impact on the GBD. They might even price their drugs below the marginal costs of production to capture a greater reward from this alternative patent scheme. The scheme would give inventors an incentive to collaborate with, rather than protest against, generic companies, country governments, and non-governmental organizations trying to alleviate the GBD. If the design details are properly worked out, Hollis' and Pogge's patent system would not create an incentive for companies to prefer drugs that treat the chronic diseases or disorders of affluent patients. Rather, companies would have an incentive to invest in those drugs that prevent the most death and alleviate the most suffering. In earlier work, Pogge said that the "cost of the plan might peak at around $\$ 45-\$ 90$ billion. With all the world's countries participating, $\$ 45$ billion amounts to 0.1 percent and $\$ 90$ billion to 0.2 percent of the global product." "iii In the proposal developed with Hollis, they advance a revised estimate of $\$ 6$ billion. ${ }^{\text {civ }}$

Unfortunately, Hollis and Pogge's proposal may also have a few problems. ${ }^{\mathrm{cv}}$ First, not all reductions in the GBD are due to an inventor's efforts. Although a new drug or investment in infrastructure might help ameliorate a disease, things non-governmental organizations or other country governments are doing, independent of the investor, may contribute more. It is not clear that Hollis and Pogge are concerned to prevent investors from receiving undue credit and investors have incentive to claim credit where it is not 
due. Second, Hollis and Pogge's current proposal relies on collecting a lot of new data by, for instance, funding expensive clinical trials. They also want an accurate estimate of impact as they plan to reward companies in proportion to their impact on the global disease burden. The necessary data is expensive and hard to collect. ${ }^{\text {cvi }}$ Finally, their proposal is quite expensive and depends on the goodwill of developed country taxpayers or donors who have historically done little to help the global poor. ${ }^{\text {cvii }}$ Unless it is well funded, it will not generate a large enough incentive for companies to risk investing in new drugs and technologies.

This paper's proposal avoids some of the problems sketched above. First, many biotechnology and pharmaceutical companies have an incentive to support the GHI proposals while almost (if not) all companies lack the incentive to do enough differential pricing, and almost all have an incentive to resist compulsory licensing and a return to the pre-TRIPS situation. Second, GHI takes full advantage of the freemarket's efficiency. A GHI rating agency need not decide what diseases or problems companies should address, nor need it determine how much inventions are worth before they are created. ${ }^{\text {cviii }}$ Rather, a GHI rating agency would reward companies based on how much their inventions and investments actually help the poor. Third, the GHI rating system is output based and could be used to incentivize companies to not only do R\&D on neglected diseases but to extend access on existing drugs and technologies to the poor. Fourth, it does not benefit companies that do not help the poor. It is supposed to capture only what companies have already done. The way this paper proposes to evaluate companies' $\mathrm{R} \& \mathrm{D}$, for instance, is by looking at what their drugs can do. It does not suggest collecting expensive new data or estimating the GBD. ${ }^{\text {cix }}$ Furthermore, it only aims to rank companies ordinally and provide a constantly raising bar for companies to try to exceed. So it is much less data-intensive than Hollis and Pogge's alternative. Fifth, although the proposal is not as ambitious as Hollis' and Pogge's, it has the advantage of being practical and relatively low cost. Although it will cost something to administer a trademark like GHI, those costs are nowhere near US \$45-90 billion (or even US \$6 billion). ${ }^{\text {cx }}$ The total revenue and support for Transfair USA, the primary Fair Trade labeling organization in the US, was US \$5,570,933 in 2006 . ${ }^{\text {cxi }}$ So, unlike Hollis' and Pogge's proposal, this one would not require taxpayer support. It could even be developed in poor countries. 
Finally, the case for GHI labeling and licensing campaigns does not depend on showing that they are better than the alternatives or establishing a hierarchy between them. The GHI proposal sketched above does not compete with any of the other proposals on the table. Rather, it can be used in conjunction with all of the alternatives to bring even greater benefits to the poor.

\section{Objections}

Even if this paper's proposal has some advantages over some of the main competitors, it may not be a good idea to pursue it. Perhaps there are better things biotechnology and pharmaceutical companies, universities, researchers, students, and consumers could do. Poor people's greatest health problems cannot be solved by better access to existing drugs and technologies or more R\&D on diseases affecting the poor. War, natural disasters, dirty water, and inadequate food provide the biggest obstacles to health in developing countries. Prevention and poverty alleviation could do much more for the poor than pills. Some anti-retrovirals, for instance, do little for the poor in parts of the world where people lack adequate nutrition without which the drugs are often ineffective.

It is impossible to decide whether there are better things agencies or individuals could do besides supporting GHI in biotechnology and pharmaceutical companies a priori. New vaccines against typhoid, cholera, and malaria or better access to antibiotics might do as much for the poor as vitamin A supplements or a few more wells. GHI might lead companies to come up with new anti-retrovirals or treatment regimes that work in the poorest places. Even if there are other things that could, in principle, benefit the poor more, there may be room for those with different interests and talents to take different approaches to ameliorating poverty. It is also possible to support GHI and provide food, vitamin supplements, and wells.

A more pressing objection is that, if a GHI rating system is put in place, highly rated companies might try to distract the public from their generally poor behaviour in other arenas. Suppose, for instance, that another organization launched a campaign to get companies to stop fighting compulsory-licensing in developing countries by lobbying US trade-representatives. Companies might respond by holding a media event to promote their GHI status and undermine the campaign. Since companies control a lot of resources, they would probably win a battle in the press. 
Companies hardly need a label, however, to hold a public relations event and undermine campaigns to get them to improve their practices. Companies can promote their charitable programs, or even start new programs to get good publicity. Those involved in the attempt to get pharmaceutical companies to improve their practices should not blame each other if companies abuse their efforts. Rather, they should stand together -the GHI review panel might even create standards for reducing companies' high ratings if they find new ways of acting poorly. Although a rating system for pharmaceutical and biotechnology companies will not solve all the poor's health problems, they may make a significant difference in many people's lives. 
i Acknowledgments with-held to preserve anonymity.

ii Center for Disease Control (CDC). 2005. World TB Day, March 24th 2005. Atlanta, GA: Division of Tuberculosis Elimination, CDC. Available at:

http://www.cdc.gov/nchstp/tb/WorldTBDay/2005/resources_progress_elimination.htm [Accessed 2 May 2008]. UNICEF. 2005. Millennium Development Goals: Combat

AIDS/HIV, Malaria, and other Diseases. Geneva: UNICEF. Available at: http://www.unicef.org/mdg/disease.html [Accessed 2 Feb 2011]. UNAIDS. 2004. World AIDS Day

2004: Women, Girls, HIV and AIDS. Geneva: AIDS Epidemic Update. UNAIDS. Available at: http://www.unaids.org/wad2004/report.html [Accessed 2 May 2008].

iii World Health Organization (WHO). 2004. World Health Report 2004. Geneva: World Health Organization.

iv Ibid.

v The World Health Organization has compiled a list of "essential" medicines in part by considering the cost of securing these medicines. Here, however, I use the term only to

indicate medicines that address dire health needs in poor countries, irrespective of the cost of addressing those needs. "This clarification should guard against the true but silly

objection that monopoly prices barely impede access to essential drugs as listed by the WHO” T. Pogge. 2007. Intellectual Property Rights and Access to Essential Medicines.

New York, NY: Global Policy Innovations. Carnegie Council for International Affairs. Available at: http://www.policyinnovations.org/ideas/policy_library/data/FP4 [Accessed 2

Feb 2011].

vi See, for instance: P. Danzon \& A. Towse. Differential Pricing for Pharmaceuticals: Reconciling Access, R\&D and Patents. Int J Health Care Finance Econ 2003; 3: 183-205.

M. Abramowicz. Perfecting Patent Prizes. Vanderbilt Law Rev 2003; 56: 114-236. P. Trouiller, E. Torreele, P. Olliaro, N. White, S. Foster, D. Wirth, \& B. Pécoul. Drugs for

Neglected Diseases: A Failure of the Market and a Public Health Failure? Trop Med Int Health 2002; 6: 945-51. K. Outterson. Patent Buy-Outs for Global Disease Innovations for

Low- and Middle-Income Countries. Am J Law Med 2006; 32: 159-73. A. Hollis \& T. Pogge. 2008. The Health Impact Fund, Making New Medicines Accessible for All: A

Report of Incentives for Global Health. Available at: http://www.keionline.org/blogs/2008/11/27/trade-off-innov-access/ [Accessed 1 Feb 2011]. The World Health Organization

has even convened an Intergovernmental Working Group (IGWG) the Secretariat on Public Health, Innovation and Intellectual Property to examine solutions to the second

problem and create a global strategy to secure "needs-driven, essential health research and development relevant to diseases that disproportionately affect developing countries."

One option the Working Group supported that is not discussed in what follows but merits significant consideration is patent pools, though this will not address pricing issues.

World Trade Organization (WTO). 2007. About PHI. Available at: http://www.who.int/phi/about/en/ [Accessed 2 Feb 2011].

vii Access to Medicines Index. 2008. Access to Medicines Index. Available at: http://www.nytimes.com/2008/06/17/health/17glob.html?_r=1\&ref=health\&oref=slogin [Accessed

1 Feb 2011].

viii Access to Medicines Index. 2010. About Us. Available at: http://www.accesstomedicineindex.org/content/about-us [Accessed 1 Feb 2011].

ix Modified from: Ibid. 
$\mathrm{x}$ When impact is too difficult to capture, however, other output variables may be useful as proxies for impact. In looking at charitable contributions, researchers might consider the number of doses of a drug donated to aid organizations in developing countries and the average impact of a dose of medicine in good conditions. This would be a very rough proxy for impact given that conditions are often far from ideal. So it would be better to have more information if it is available.

xi M. Angell. 2004. The Truth About the Drug Companies: How They Deceive Us and What To Do About It. New York, NY: Random House.

xii A good rating system need not measure every way in which companies can improve health in developing countries. Furthermore, the most weight should probably be given for activities for which biotechnology and pharmaceutical companies have primary responsibility. Still, biotechnology and pharmaceutical companies do invest in health

infrastructure and rewarding them for these investments will help insure that they not only have incentives to cure illnesses but also to prevent them.

xiii There is some work on how to help companies in developing countries meet local health needs. See, for instance, the Innovation, Knowledge and Development Project at the

Open University IKD. 2009. Non-governmental Action to Improve the Access of the Poor to Good Quality Low Cost Drugs. IKD Projects. Available at:

http://www.open.ac.uk/ikd/projects_lowcostdrugs.shtml [Accessed 1 Feb 2011].

xiv For similar proposals see: T. Hubbard \& J. Love. 2004. A New Trade Framework for Global Healthcare R\&D. PLoS Biology2: e52 Available at:

http://www.plosbiology.org/article/info:doi/10.1371/journal.pbio.0020052 [Accessed 1 Feb 2011]. A. Hollis \& T. Pogge. 2008. The Health Impact Fund, Making New Medicines Accessible for All: A Report of Incentives for Global Health. Available at: http://www.keionline.org/blogs/2008/11/27/trade-off-innov-access/ [Accessed 1 Feb 2011]. Different

authors disagree about the merits of the available measures of an intervention's impact. Some, for instance, prefer to measure an intervention's impact on quality adjusted life years (QUALYs). Given this disagreement, a good rating agency should consider the merits of the different measures for the task at hand.

xv It may be hard to isolate and measure the impact of health projects. An agency would have to transparently and systematically determine how much different investments in approved health-projects help the poor. Perhaps the agency could induce companies to provide this information as a condition of certification. But, biotechnology and pharmaceutical companies would have reason to try to distort these estimates. So, one place to start would be to evaluate the 126 health partnerships the pharmaceutical industry reported to the International Federation of Pharmaceutical Manufacturers \& Associations in 2006 which have been verified by researchers at the London School of Economics A. de Francisco \& S. Matlin, eds. 2006. Monitoring Financial Flows for Health Research 2006: The Changing Landscape of Health Research for Development. Geneva: Global Forum for Health Research.

xvi More precisely, orphan drugs address rare diseases in the US. As the US Food and Drug Administration puts it, "...the term rare disease or condition means any disease or condition which (a) affects less than 200,000 persons in the US or (b) affects more than 200,000 persons in the US but for which there is no reasonable expectation that the cost of developing and making available in the US a drug for such disease or condition will be recovered from sales in the U.S. of such drug." Food and Drug Administration (FDA). 
xvii A rating agency might also want to provide more incentive for companies to develop drugs and technologies that will have a large impact on the poor even if they have a large market in developed countries. So this agency might, for instance, also offer companies credit for producing drugs that address diseases on the WHO's list neglected diseases.

xviii Angell, op.cit. note 10 .

xix Once the rating system is up and running, the agency could make it a condition of being GHI certified that companies provide verifiable data on the number of doses they sell

by a particular date.

xx For some GBD data see: World Health Organization. 2011. The Global Burden of Disease: 2004 Update. Available at:

http://www.who.int/healthinfo/global_burden_disease/en/index.html [Accessed 2 Feb 2011].

xxi Ibid.

xxii World Health Organization (WHO). 2010. Global Report on Antimalarial Drug Efficacy and Drug Resistance: 2000-2010. Geneva: World Health Organization: 112.

xxiii Since Mefloquine is less effective than Quinine, unless it offers some other therapeutic advantages over Quinine (it is a synthetic analogue), there may be no reason to give

credit Roche Pharmaceuticals for the development of this drug.

xxiv The agency might also consider the problems associated with drugs and technologies in estimating their net benefits (e.g. some drugs have pretty bad side effects that should

probably be taken into account, others require difficult to implement treatment regimes ).

xxv Taking into account companies' size will allow new or very small companies making only a few drugs to compete for good ratings. A rating agency might only rate large companies, however, if that is the best way to incentivise new R \&D on drugs and technologies for the poor.

xxvi See, for instance: M. Drummond, M. Sculpher, \& K. Claxton. 2005. Methods for the Economic Evaluation of Health Care Programmes. Oxford: Oxford University Press.

xxvii Ibid.

xxviii Again, this information might be elicited from the companies as a condition of certification. The rating agency could also charge certification fees for advertising or rely on

highly rated companies to do this advertising. It is important to minimize problematic incentives in rewarding charitable programs too.

xxix P. Kanavos, J. Costa-i-Font, S. Merkur, \& M. Gemmill. 2004. The Economic Impact of Pharmaceutical Parallel Trade in European Union Member States. Special Research

Paper LSE Health and Social Care. London: London School of Economics and Political Science.

$\mathrm{xxx}$ It is important to take the costs of government oversight into account, however, if it proves necessary.

xxxi A review panel could, for instance, create a mechanism to penalize companies for "dumping" drugs on developing country markets if donations do more harm than good for

the poor because they are driving generic competitors out of business. This would insure that companies only receive credit for making donations on the condition that they are

given in ways that will not have such consequences. 
xxxii In 1986, the market for pain relievers was 1.7 billion dollars. Ibuprofen pain relievers only captured nine percent of the market New York Times. 1986. Analgesic Makers in a Battle. February 18, 1986. Available at: http:/query.nytimes.com/gst/fullpage.html?sec=health\&res=9A0DE7D91F31F93BA25751C0A960948260 [Accessed 2 February 2011]. For statistics on Fair Trade coffee see: EFTA cited in L. Raynolds. 2002. Poverty Alleviation Through Participation in Fair Trade Coffee Networks: Existing Research and Critical Issues. Background Paper Prepared for Project Funded by the Community and Resource Development Program. New York, NY: The Ford Foundation.

xxxiii See: Chain Drug Review. 2009. Internal Analgesic Tablets Available at: http://www.walgreens.com/search/results.jsp?Ntt=advil + pm\&x=0\&y=0 [Accessed 21 Jun 2010]. xxxiv Raynolds, op.cit. note 31.

xxxv Ibid.

xxxvi Ibid.

xxxvii Fairtrade Labeling Organization (FLO). 2009. Facts and Figures. Available at: http://www.fairtrade.net/facts_and_figures.html?\&L=\&scale=0 [Accessed 1 Feb 2011].

xxxviii The Global Fund to Fight AIDS, Tuberculosis and Malaria. 2011. (Product)REDTM Generates Landmark \$US150 Million for The Global Fund.” Available at: www.theglobalfund.org/en/pressreleases/?pr=pr_100601 [Accessed 12 Feb 2011].

xxxix The Cooperative Bank. 2007. Ethical Consumerism Report 2007. Available at: http://www.co-operativebank.co.uk/images/pdf/ethical_consumer_report_2007.pdf [Accessed 1 Feb 2011].

xl The biggest pharmaceutical company, Pfizer, has revenues of about 48 billion dollars per year. Pfizer. 2009. Pfizer Reports Fourth-Quarter and Full-Year 2008 Results and 2009 Financial Guidance. Available at: http://media.pfizer.com/files/investors/presentations/q4performance january012609.pdf [Accessed 1 Feb 2011]. But a quick web search suggests that at least three of the 23 companies producing the 26 orphan drugs with the most potential to benefit the poor only have revenues or sales between $1-10$ million dollars a year. This list was selected by a panel of three experts in international health at the University of Pittsburgh Medical Center. Contact the author for further information. Revenue estimates were found here: Jigsaw. 2007.Hoechst Marion Ruussel Company Information. Available at: http://www.jigsaw.com/id150236/aventis_hoechst_marion_roussel_company.xhtml [Accessed 2 May 2008]. Jigsaw. 2010. Romark Laboratories Lc Company Information. Available at: http://www.jigsaw.com/id2028996/romark laboratories_lc company.xhtml [Accessed 1 Feb 2011]. Jigsaw. 2011. Braintree Labortories Inc. Company Information. Available at: http://www.spoke.com/info/c494unR/BraintreeLaboratoriesInc [Accessed 1 Feb 2011]. Many of these companies make products for developed country markets or merge with other small companies that do so. See, for instance: Braintree Labroatories. 2010. Products. Available at: http://www.braintreelabs.com/products-suprep.htm [Accessed 1 Feb 2011].

xli See XX. 
xlii BBC Research. 2002. The U.S. Market for Prescription Allergy Treatment and Management Report Code: PHM026A. Available at:

http://www.bccresearch.com/report/PHM026A.html [Accessed 1 Feb 2011].; Kalorama Information. 2001. The U.S. Market for Over-the-Counter Allergy and Asthma Products.

Available at: http://www.marketresearch.com/product/display.asp?ProductID=521895 [Accessed 1 Feb 2010].

xliii A.S. Kesselheim. Think Globally, Prescribe Locally: How Rational Pharmaceutical Policy in the U.S. Can Improve Global Access to Essential Medicines. Am J Law Med

2008; 34: 125-139.

xliv L.A. Mahecha. 2006. Outlook: Rx-to-OTC Switches: Trends and Factors. Available at: http://www.nature.com/nrd/journal/v5/n5/fig_tab/nrd2028_F3.html [Accessed 1 Feb 2011].

xlv Sometimes companies may not want to use a label on generic products if the would prefer their customers buy their higher priced brand name drugs. But they can choose to use the label only on their brand name products if that is the case.

xlvi For statistics see: Ibid.

xlvii Pfizer. 2010. Diversified Business. Available at: http://pfizer.com/research/licensing/diversified_business.jsp [Accessed 1 Jan 2011].

xlviii Perhaps this consideration also tells in favor of a label that says something like Extending Access rather than GHI for companies that are just the best out of a bad lot. The

GHI label might be reserved for companies that really are doing what they should.

xlix Transfair USA, for instance, has never had to take anyone to court for misusing their label, a conversation usually suffices to either get companies to stop using the label or

adhere to their standards for certification. C. Sinclair. 2009. Business development associate Transfair USA. Phone interview conducted by author. Aug 132009.

1 Some worry that the agriculture lobby succeeded in lowering standards for calling something "organic". But, even if the standards are not quite as good as one might like, the

USDA does oversee the use of the pesticides and other farming practices that motivated the organic movement in the first place. United States Department of Agriculture (USDA).

2007. National Organics Program. Available at: http://www.ams.usda.gov/nop/NOP/standards/ListReg.html [Accessed 2 Feb 2011].

li Even the Norwegian government uses some socially responsible investment criteria in investing its pension funds. A. Follesdal. Ethical Investment and Human Rights: A

Norwegian Case. Nordic Journal of Human Rights. 2007; 25: 420-433.

lii I have discussed the proposal with the director of UAEM and he expressed interest in the project. Universities Allied for Essential Medicine (UAEM). 2008. Phone interview

by author with Ethan Guillan, Director. Aug 32008.

liii Universities Allied for Essential Medicine (UAEM). 2009. Our Proposals. Berkeley, CA: UAEM. Available at: http://www.essentialmedicine.org/our-proposals/ [Accessed 2

May 2010]. 
liv Association of American Universities (AAU). 1998. University Technology Transfer of Government-Funded Research Has Wide Public Benefits. Washington, D.C.: AAU.

Available at: http://www.aau.edu/research/TechTrans6.3.98.html [Accessed 2 May 2008]

lv One might get a sense of how much technology industry is licensing in by considering how much of the research going into its products is coming from universities. "The NIH

had selected the five top-selling drugs in 1995 (Zantac, Zonirax, Capoten, Vasotec, and Prozac) and found that sixteen of the seventeen key scientific papers leading to their

discovery and development came from outside the industry. (Eli Lilly had sponsored one of the four key studies leading to the development of Prozac.) Looking at all the relevant published research, not just at the key studies, only 15 percent came from industry, whereas 55 percent came from NIH-funded laboratories and 20 percent from foreign academic institutions.” J. DiMasi, R. Hansen, \& H. Grabowski. The Price of Innovation: New Estimates of Drug Development Costs. J Health Econ 2002; 22: 151-85. cited in Angell, op.cit. note 10. Furthermore, "A recent study published in the journal of Health Affairs reported that, in 1998, only about 15 percent of the scientific articles cited in patent applications for clinical medicine came form industry research, while 54 percent came from academic centers, 13 percent from government, and the rest from various other public and nonprofit institutions. Remember that these are patent applications for all new drugs and medical innovations, not simply for those ultimately judged to be clinically important. Had the data been limited to major breakthrough drugs, the industry's role would undoubtedly have been even smaller. An unpublished internal document produced by the NIH in February 2000, which was obtained by Public Citizen through the Freedom of Information Act, revealed similar percentages.” Ibid: 64.

lvi Angell, op.cit. note 10.

lvii University technology transfer yielded around \$25 billion in 1996 AAU, op.cit. note 56. G. Harris. 2003. Will the Pain Ever Let Up for Bristol-Myers? New York Times 18

May: 3.

lviii On changing patterns in pharmaceutical company innovation see: National Institute for Health Care Management Foundation (NIHCMF). 2002. Changing Pattern of

Pharmaceutical Innovation. Washington, D.C.: NIHCMF.Available at: www.nihcm.org/finalweb/innovations.pdf [Accessed 2 May 2008].

lix Marcia Angell. 2007. Email correspondence. October, 29, 2007.

lx These included captopril (Capoten), fluoxetine (Prozac), acyclovir (Zovirax), AZT, acyclovir, fluconazole (Diflucan), foscarnet (Foscavir), and ketoconazole (Nizoral). For more information see: Joint Economic Committee (JEC). 2000. The Benefits of Medical Research and the Role of NIH. Washington, D.C.: JEC. Available at: http://www.faseb.org/portals/0/pdfs/opa/2008/nih_research_benefits.pdf [Accessed 2 February 2011].

lxi Furthermore, a lot of funding for universities comes from government, so this graph probably understates the government's role. lxii Modified from: de Francisco \& Matlin, op. cit.note 18, p. 41.

1xiii Consumer Project on Technology (CPT). 2005. The Bayh-Dole Act. Geneva: CPT. Available at: http://www.cptech.org/ip/health/bd/ [Accessed 1 Feb 2011]. 
lxiv Universities Allied for Essential Medicine (UAEM). 2007. Why Universities? Berkeley, CA: UAEM. Available at: http://www.essentialmedicine.org/?page_id=97 [Accessed 2 May 2008].

lxv Ibid. The Stevenson-Wydler act similarly allowed NIH-funded research to be patented and then licensed to drug companies. The companies market the drugs and then sometimes patent them for other uses. If a similar campaign could get the NIH to deal only with highly-rated companies, this might help people access essential medicines and technologies as well. After all, the NIH has helped create essential drugs like AZT (which was developed by NIH in conjunction with Duke and then licensed to GlaxoSmithKline) Angell, op. cit. note 10, p. 57.

lxvi The Association of University Technology Managers licensing surveys provide information about almost 200 major universities' budgets, research expenditures, and licensing agreements as well as other useful information. See: The Association of University Technology Managers (AUTM). 2007. FY 2005 AUTM U.S. Licensing Survey. Northbrook, IL: AUTM. Available at: http://www.autm.net/AM/Template.cfm? Section=Licensing_Surveys_AUTM\&TEMPLATE=/CM/ContentDisplay.cfm\&CONTENTID=4510 [Accessed 2 February 2011]. The Association of University Technology Managers (AUTM). 2005. AUTM U.S. Licensing Survey FY2005. Northbrook, IL: AUTM. Available at: http://www.autm.net/AM/Template.cfm? Section=Licensing_Surveys_AUTM\&TEMPLATE=/CM/ContentDisplay.cfm\&CONTENTID=4510 [Accessed 2 May 2008]. Also see: http://www.autm.net/about/dsp.Detail.cfm?pid=194 [Accessed 2 May 2008].

lxvii NIHCMF, op.cit. note 60 .

lxviii Angell, op.cit. note 10, p. 247.

lxix Another point of contact between universities and companies is when companies want to do clinical and pre-clinical trials. Universities could require that any research funded by pharmaceutical and biotechnology companies, even if it does not result in university owned intellectual property, be done only in conjunction with GHI certified companies. This kind of policy, however, will probably not be accepted by university researchers whose careers depend on such research contracts. lxx Universities often create start up companies or license to start up companies that, being new, could not themselves be GHI certified. These companies test and develop products using university technology. Eventually these companies are sold or sell their technology to larger companies that could be GHI certified. So down-stream clauses in licensing contracts may be necessary and desirable.

lxxi M. Vanegas. 2007. Technology Licensing Associate. Life Sciences. Interview Conducted by Author. Pittsburgh, PA: University of Pittsburgh Office of Technology Management. The University of Pittsburgh's Office of Technology Management alone generated 7.1 million dollars in revenue in 2007 in licensing revenue, equity cash-outs, legal fee reimbursements from licensees. Licensing revenue alone was 4.9 million dollars and its equity in the start up Novecea generated 92,000 dollars, finally its spinout Stentor Inc. was sold for 6.7 million dollars. Office of Technology Management (OTM). 2007. Annual Report 2007. Pittsburgh, PA: OTM University of Pittsburgh: 7-8. 
lxxii AUTM, op.cit. note 68.

lxxiii About $20 \%$ of Stanford faculty members had industry funding in 2004. About 30\% of Stanford's faculty resided in the medical school. R. Delgado. 2005. Slow Growth Seen In Faculty Ranks; Challenges Remain In Hiring Minorities, Women. Stanford Report. Available at: http://news-service.stanford.edu/news/2005/may4/faculty-050405.html

[Accessed 1 Feb 2011]. Of course, not all of this funding would have been from pharmaceutical companies but pharmaceutical companies probably fund some non-medical faculty so it might be reasonable to suppose that $20 \%$ of the medical faculty had pharmaceutical funding at Stanford. If that is right, then about $7 \%$ of Stanford's faculty were funded by pharmaceutical companies. Another way of getting at the proportion of industry funding from pharmaceutical companies is to suppose that the percentage of the medical faculty at Stanford receiving industry funding is about the same as the percentage of medical faculty receiving industry funding on average. If it is, then $25 \%$ of medical faculty at Stanford had industry funding. Again, other industries may account for some of this funding but pharmaceutical companies may fund non-medical faculty as well. So it seems reasonable to conclude (again) that $7 \%$ of the Stanford faculty had pharmaceutical funding. Stanford, however, has a large medical school and most universities and colleges probably receive much less industry funding.

lxxiv UAEM, op.cit. note 68 .

lxxv AUTM, op.cit. note 68.

lxxvi UAEM, op. cit. note 55. The moral justification for this campaign would probably differ from USAS's since it is different to make goods that essentially and directly rely on the labor of the poor than to make goods that simply ignore the needs of the poor.

lxxvii This assumes $30 \%$ of pharmaceutical companies' research is done at universities, so that similar success would ensure that at least $2 \%$ of the research funds benefit the poor. Since US academic centers spent over 42 billion dollars in R \& D in 2005, 2\% of 42 billion dollars is 840 million dollars a year AUTM, op. cit. note 68 . As noted above, universities are only getting about 240 million a year from licenses but they get more from the biotechnology companies they create. For instance, "Columbia University, which patented the technology used in the manufacture of Epogen and Cerezyme, collected nearly $\$ 300$ million in royalties from more than thirty biotechnology companies over the seventeen-year life of the patent" Angell, op. cit. note 10, p. 71. And some of this incentive would presumably come from other downstream companies too. How much incentive companies will have will depend on how much the universities are willing to demand.

lxxviii The estimate assumes that 30 percent of the drugs these companies rely upon are coming from universities, in line with other authors' estimates. Marcia Angell reports, for instance, that "In 2002, for example, Pfizer licensed in 30 percent of its drugs, and Merck 35 percent" Angell, op. cit. note 10. All of Bristol-Myers Squibbs' best selling drugs in 2003 wre licensed Harris, op.cit. note 59. Pharmaceutical companies probably acquire even more of their most innovative drugs from universities. For independent work suggesting R\&D costs are much lower see: D. Light, J. Kim A., R. Warburton. Estimated Research and Development Costs of Rotavirus Vaccines. Vaccine $2009 ; 27$. lxxix Trouiller et. al, op. cit. , note 6 . 
lxxx There are a host of alternatives in the interdisciplinary literature on the topic that merit consideration. Some suggest better prediction of demand for medicines for neglected diseases R. Levine, J. Pickett, N.Sekhrf, \&P. Yadav. Demand Forcasting for Essential Medical Technologies. Am J Law Med 2008; 34: 225-255. Others encourage developing countries to form alliances with each other and reform their patent offices P.Yu. Access to Medicines, BRICS Alliances, and Collective Action. Am J Law Med 2008; 34: $345-$ 394.; P. Drahos. 'Trust Me': Patent Offices in Developing Countries. Am J Law Med 2008; 34: 151-174. Yet others, endorse international organizations' move towards promoting development. J. Lerner. Intellectual Property and Development at WHO and WIPO. Am J Law Med 2008; 34: 257-277. Some even suggest changing university licensing practices to allow greater access to the fruits of university research. G. Evans. Strategic Patent Licensing for Public Research Organizations: Deploying Restriction and Reservation Clauses to Promote Medical R\&D in Developing Countries. Am J Law Med. 2008; 34: 175-223.

lxxxi Abramowicz, op.cit. note 6. Pharmaceutical R\&D Policy Project. 2005. The Landscape of Neglected Disease Drug Development. London: Wellcome Trust and London School of Economics. A. Faunce \& H. Nasu. 2008. Three Proposals for Rewarding Novel Health Technologies Benefiting People Living in Poverty: A Comparative Analysis of Prize Funds, Health Impact Funds and a Cost-effectiveness/Competitive Tender Treaty. Public Health Ethics 1. Available online at: http://phe.oxfordjournals.org/cgi/reprint/phn013v1 [Accessed 1 Feb 2011]. E. Berndt., R. Glennerster, M. Kremer, J. Lee, R. Levine, G. Weizsacker, \& H. Williams. Advance Market Commitments for Vaccines Against Neglected Diseases: Estimating Costs and Effectiveness. Health Econ 2007; 16: 491-511. Danzon and Towse, op.cit. note 6. OHE Consulting. 2005. A Review of IP and Non-IP Incentives for R\&D for Diseases of Poverty: What Type of Innovation is Required and How Can We Incentivise the Private Sector to Deliver It? Final Report for the WHO Commission on Intellectual Property Rights, Innovation and Public Health. London: Office of Health Economics.

lxxxii Danzon and Towse, op.cit. note 6.

lxxxiii S. Flynn, A. Hollis \& M. Palmedo. An Economic Justification for Open Access to Essential Medicine Patents in Developing Countries. J Law Med Ethics 2009; $37: 184$. lxxxiv J. Lanjouw \&W. Jack. 2004. Trading Up: How Much Should Poor Countries Pay to Support Pharmaceutical Innovation. Center for Global Development. Available at: http://www.cgdev.org/content/publications/detail/2842 [Accessed 1 Feb 2011]. Although intellectual property rights encourage the development of new drugs and technologies, these rights may also prevent the poorest from securing existing drugs and technologies. The TRIPS agreement requires WTO member countries to grant 20 year patent protection for new drugs and technologies. The so-called "TRIPS-Plus" provisions require countries to allow these patents to be "ever-greened" beyond the 20 year mark and discourage generic competition. biotechnology and pharmaceutical companies can apply for patents on many "trivial or irrelevant" aspects of their drugs and technologies like packaging or dosing regimen to extend protection beyond the life of their primary patent. They must then be notified before generics can be produced and get an automatic 30 -month extension on their patent. Sometimes they try to extend protection further with legal action. Often generic drugs must be tested again before being put on the market even if they are basically equivalent to patented versions. This expensive testing can delay generic entry into the market. See: Federal Trade Commission (FTC). 2002. Generic Drug Entry Prior to Patent Expiration: An FTC Study. Washington, D.C.: FTC Available at: www.ftc.gov/os/2002/07/genericdrugstudy.pdf [Accessed 1 Feb 2011]. S. Sell. What Role for 
Humanitarian Intellectual Property? The Globalization of Intellectual Property Rights. Minnesota Journal of Science and Technology 2004; 6: 191-211. Also see: NIHCMF,

op.cit. note 60 .

lxxxv See: Kanavos op.cit.

lxxxvi D. Barnard. In the High Court of South Africa, Case No. 4138/98: The Global Politics of Access to Low-Cost AIDS Drugs in Poor Countries. Kennedy Inst Ethics J

2002;12: 159-174. J.H. Reichman. Comment: Compulsory Licensing of Patented Pharmaceutical Inventions: Evaluating the Options. J Law Med Ethics 2009; $37: 247$ - 263. K.

Outterson. Forthcoming. Disease-Based Limitations on Compulsory Licenses Under Articles 31 and 31 bis. In Research Handbook on Intellectual Property Law and the WTO. C.

Correa, ed. Cheltenham: Edward Elgar Press. "The combined worth of the world's top five drug companies is twice the combined GNP of all Sub-Sahran Africa" Global Health

Watch (GHW). 2005. Global Health Watch 2005-2006: An Alternative World Health Report. New York, NY: Zed Books: 103. In 2002 the 10 largest pharmaceutical companies

made over $\$ 39$ billion, more than half of the total profits of Fortune 500 companies. "With such profits at stake, it is no surprise Big Pharma invests a huge amount of money in

protecting them.” Ibid: 103.

lxxxvii Banard, op.cit. note 87 .

lxxxviii Similarly, when Thailand issued a compulsory license for Efavirenz an HIV/AIDS drug produced by Merck the US government was displeased. See: J. McDermott. 2006.

A Morality Tale on AIDS. Available at: www.house.gov/mcdermott/sp060619.shtml [Accessed 20 June 2006].

lxxxix For an account of Australia's difficulties in extending access to essential drugs and technologies to its population under TRIPS see GHW, op. cit. note 88, p. 106. The

administrative burden of trying to issue a compulsory license may also provide a road block to doing so. Ibid.

xc Banard, op.cit. note 87.

xci Ibid. R.Steinbrook. Closing the Affordability Gap for Drugs in Low-Income Countries. N Engl J Med 2007 357: $1996-1998$.

xcii WTO, op.cit. note 6 .

xciii Ibid.

xciv P. Goodwin. Right Idea, Wrong Result - Canada's Access to Medicines Regime. Am J Law Med 2008; 34: 567-584.

xcv See: H.E. Msgr. Diarmuid Martin. 2002. Intervention by the Holy See at the World Trade Organization. Available at:

http://www.vatican.va/roman_curia/secretariat_state/documents/rc_seg-st_doc_20021220_martin-wto_en.html [Accessed 1 Feb 2011].

xcvi The agreement was amended to make it easier to compulsory license essential drugs and technologies WTO, op. cit. note 6.

xcvii P. Drahos. 2002. Global Intellectual Property Rights: Knowledge, Access and Development. New York, NY: Palgrave MacMillion. S. Sell. 2003. Private Power, Public

Law: The Globalization of Intellectual Property Rights. Cambridge Studies in International Relations. Cambridge: Cambridge University Press. 
xcviii M. Kremer \& R. Glennerster. 2004. Strong medicine: Creating Incentives for Pharmaceutical Research on Neglected Diseases. Princeton, NJ: Princeton University Press.

W. Fisher \& T. Syed. Forthcoming. A Prize System as a Partial Solution to the Health Crisis in the Developing World. In Drugs, Law, and the Health Crisis in the Developing

World. Stanford, CA: Stanford University Press. Outterson, op.cit. note 6. A more recent alternative is another licensing and rating proposal - Universities Allied for Essential

Medicines' (UAEM) Equal Access License (EAL) and their metric for rating university technology transfer offices. UAEM's proposals are promising and it is probably too soon

to know if they will succeed. Their metric, however, looks only at technology transfer offices' policies rather than the impact of these policies UAEM, op. cit. note 54. While good

policies probably promote good outcomes, it would be better to look at the impact these offices are having. The EAL license is also step in the right direction but may not do

enough. It allows generic companies access to new research. It does nothing to help the poor secure access to existing drugs and technologies or encourage other biotechnology

and pharmaceutical companies to do research on neglected diseases. UAEM, op. cit. note 55.

xcix Such alternatives may be more cost-effective than prize funds. With prize funds, the prizes have to be large enough to compensate for the risk to companies of not being able to develop an acceptable invention or not being the first to do so. See: Kremer \& Glennerster, op.cit. note 99.

c TB Alliance. 2006. Gates Foundation, Novartis Embark on Public-Private Ventures to Combat TB and Malaria. Available at: http://72.3.224.152/newscenter/view-innews.php? id=173 [Accessed 2 Feb 2011].

ci A bidding system might provide a partial solution to this problem. On this see: Pogge, op. cit. note 5.

cii Hollis \& Pogge, op. cit. note 6. Hollis and Pogge's proposal is similar in some ways to the proposal advanced in Hubbard \& Love, op. cit. note 5. Hubbard and Love suggest separating out markets for R\&D from markets for end products (putting the later in the public domain and funding the former through tax contributions).

ciii Pogge, op.cit. note 5. Pogge seems to think that this way of incentivizing companies to do new R\&D will be less expensive than prize funds which have to come up with big enough prizes to compensate companies for not being the first to develop a new drug or technology. I do not see how this problem is not a general one for incentivizing companies to do new R\&D. Presumably only one company can have a patent under Pogge's schema for a particular condition, so companies have to take into account the risk of doing R\&D but not being the company to get the patent.

civ Hollis \& Pogge, op.cit. note 6.

cv It is not clear that we ought, even on Pogge's moral theory, to try to minimize the GBD rather than the disease burden of those our shared institutions have harmed (until everyone's human rights are satisfied). It may be better to just try to aid the poor. Because this is a very complicated (and partly empirical) question I will not discuss this difference between our proposals further here.

cvi M.J. Selgelid. A Full-Pull Program for the Provision of Pharmaceuticals: Practical Issues. Public Health Ethics 2008; 0: 1-12. Selgelid's delightful article discusses some of the difficulties in framing the rating question and evaluating companies' efforts. The issues he raises merit further consideration. 
cvii It is not at all clear how Pogge estimates his program's cost but it might cost quite a bit more than he imagines to really make an impact as drug companies report average

R\&D costs in the hundreds of millions. Angell, op. cit. note 10 .

cviii A potential draw back is that the proposal's success depends on what may be fickle and easily manipulated consumer preferences.

cix The counter-factual relative to which something counts as an improvement should probably approximate the current situation as closely as possible. There are some other ways

of dealing with any bad incentives this creates. For discussion see: Selgelid, op.cit. note 108.

cx Hollis \& Pogge, op. cit. note 6 .

cxi They have never even had a lawsuit in defense of their label though two people at the organization help prevent abuse by contacting those who infringe on their copyright they

rely primarily upon their customer base for monitoring. Sinclair, op. cit. note 51. 